\title{
Vaccine Therapy
}

National Cancer Institute

\section{Source}

National Cancer Institute. Vaccine Therapy. NCI Thesaurus. Code C15347.

Immunotherapy using a preparation that usually contains a complex mixture of diseaserelated antigens, immunopotentiating agents, and immunomodulators, which stimulate the immune system to destroy pathogenic microorganisms or tumor cells. 